УДК 616.132.2-007.272-089.819.5+616.06

\title{
Аналіз ускладнень при проведенні рентген-ендоваскулярної реканалізації у хворих із хронічною оклюзією коронарних артерій
}

\author{
Аксьонов Є. В., Головенко В. Б. \\ ДУ «Національний інститут серцево-судинної хірургії імені М. М. Амосова НАМН України» (Київ)
}

\begin{abstract}
Робота присвячена вивченню та аналізу ускладнень при проведенні рентген-ендоваскулярної реканалізації хронічної коронарної оклюзії (ХКО) у пацієнтів з ішемічною хворобою серця.

В обстеження увійшло 365 пацієнтів із ХКО, яким на базі рентген-ангіографічного відділення НІССХ імені М. М. Амосова НАМН України проводились діагностичні та лікувальні інтервенційні процедури з приводу даної патології.

Середній вік пацієнтів становив $66,96 \pm 1,81$ років, середня вага $-86,5 \pm 1,44$ кг.

Тривалість оклюзії відраховували від моменту перенесеного інфаркту міокарда (IM) в басейні інфарктпов'язаної коронарної артерії (KA).

Тривалість оклюзії від 3 до 6 місяців відзначалася у 26,8\% пацієнтів (98 хворих). Термін оклюзії від 6 до 12 місяців реєструвався у 37,5\% пацієнтів (137 осіб). Загальну тривалість оклюзії від 1 року до 3 років мали $35,6 \%$ пацієнтів (130 хворих).

В результаті виконаних досліджень було визначено, що найбільший відсоток ускладнень у досліджуваній групі припадав на IM (1,1\% випадків). В основі розвитку даного ускладнення лежала неможливість ефективно реканалізувати оклюзовану КА і тривалість ангіографічної процедури. При цьому частота розвитку IM була порівнянна між процедурами, які мали $100 \%$ ангіографічний успіх, і процедурами, які не дозволили провести ефективну реканалізацію.

Порівняно з успішними процедурами невдалі процедури мали значно вищі показники «великих» перипроцедуральних ускладнень.

Найбільший відсоток «малих» ускладнень припадав на контраст-індуковану нефропатію $(4,9 \%)$, незначні кровотечі $(3,28 \%)$ і ускладнення з боку судинного доступу, що не потребували хірургічної корекції $(1,1 \%)$.
\end{abstract}

Ключові слова: реканалізація, хронічна оклюзія, коронарні артеріі.

Хронічна коронарна оклюзія (ХКО) зустрічається у $15-30 \%$ пацієнтів, яким проводиться діагностична коронарографія $[1,2]$. Однак, з огляду на низький процедурний коефіцієнт успіху і технічні складності проведення реканалізації у подібної категорії хворих, рентген-ендоваскулярні втручання такого характеру становлять певну складність [3].

Поява і подальше широке використання стентів наприкінці 1990-х - на початку 2000-х років було значним кроком до збільшення показників процедурального успіху черезшкірної коронарної реваскуляризації і підвищило успішність рентген-ендоваскулярних операцій при ХКО з $50 \%$ до 70\% [4].

Проте в роботах Patel V. G. і співавт. звертається увага на різноманітність і неординарність процедуральних ускладнень, які виникають при коронарній реваскуляризації ХКО [5]. Найбільш поширеними ускладненнями, як відзначають автори даної роботи, були незначні кровотечі/судинні події $(4,8 \%)$, перфорація $(2,4 \%)$ і контраст-індукована нефропатія $(1,8 \%)$ [5]. Життєзагрозливі ускладнення були зареєстровані в
3,9\% випадках: летальний результат - у 0,3\% пацієнтів, інсульт/транзиторна ішемічна атака - у 0,3\% хворих, клінічний інфаркт міокарда - в $0,9 \%$ випадках, тампонада серця фіксувалася у $0,3 \%$ обстежених, кровотечі - у 0,9\% пацієнтів [5].

Rathore S. і співавт. виявили, що помірна і важка кальцифікація та звивистість коронарних артерій (KА) при ХКО є предикторами невдалої інтервенційної процедури стентування вінцевих судин [6].

У роботах інших авторів зазначається, що ретроградний підхід був пов'язаний із 2,1-кратним збільшенням шансів будь-якого перипроцедурального ускладнення [5]. При цьому використання ретроградного підходу може піддати пацієнта серйозним процедурним ризикам (таким, як диссекція донорської судини) [5, 6].

У систематичному огляді літератури, представленомy Shorrock D. і співавт., було опубліковано 107 випадків аортокоронарної диссекції під час рентген-ендоваскулярної коронарної реканалізації, які мали місце головним чином у правій коронарній артерії $(74,8 \%)$ i 
були піддані стентуванню (49,5\%), екстреній коронарній шунтуючій хірургії (29\%) [7].

Ризик втрати стента під час ангіографічних операцій у пацієнтів і XКО стоїть особливо гостро, тому що в даної категорії хворих коронарні сегменти мають звивистий і кальцинований характер [8].

У роботах Mehran R. і співавт. загострюється увага на ще одному ускладненні, яке може розвиватися у пацієнтів з ХКО під час проведення стентування оклюзованого сегмента, - на перфорації КА [9]. I хоча це ускладнення може бути зареєстроване з частотою близько 2,4\% випадків, у пацієнтів із ХКО воно найчастіше виникає у вигляді дистальних перфорацій i може нести загрозу тампонади навіть через декілька годин після закінчення процедури [10].

Таким чином, проведення черезшкірної реканалізації коронарних артерій у пацієнтів із ХКО на сьогоднішній день залишається актуальним завданням, що потребує детального дослідження та аналізу.

Метою даної роботи був аналіз ускладнень при проведенні рентген-ендоваскулярної реканалізації хронічної коронарної оклюзії у пацієнтів з IXC.

Матеріали та методи дослідження. У представлене дослідження було включено 365 пацієнтів із ХКО, яким на базі рентген-ангіографічного відділення НICCX імені М. М. Амосова НАМН України проводилися діагностичні та лікувальні інтервенційні процедури з приводу даної патології.

Вік пацієнтів коливався від 62 років до 73 років (у середньому $66,96 \pm 1,81$ років). Середня вага становила $86,5 \pm 1,44$ кг (від 67 кг до 102 кг).

Усі пацієнти були обстежені згідно з протоколом, прийнятим у НICCX імені М. М. Амосова НАMН України для даної категорії хворих.

Радіальний доступ застосовувався у $94,1 \%$ випадках, феморальний - у 5,9\% пацієнтів.

Гемодинамічно значущою вважалася оклюзія просвіту артерії більше $50 \%$.

Тривалість оклюзії відраховували від моменту перенесеного інфаркту міокарда (IM) в басейні інфарктпов'язаної коронарної артерії (КА).

Тривалість оклюзії від 3 до 6 місяців відзначалася у 26,8\% пацієнтів (98 хворих). Термін оклюзії від 6 до 12 місяців реєструвався у 37,5\% пацієнтів (137 осіб). Загальну тривалість оклюзії від 1 року до 3 років мали $35,6 \%$ пацієнтів (130 хворих).

Процедура рентген-ендоваскулярного стентування виконувалася відповідно до стандартних методик. Рутинна терапія, що проводилася під час ангіопластики, включала нітрати, клопідогрель і гепарин. Технічні аспекти процедури, що включають вибір стента і балона, тривалість інфляції і тиску, визначалися кожним оператором індивідуально.

Статистична обробка отриманих результатів була проведена з використанням програм «Excel 2007» для
Microsoft Office i Statistica 6.0, з використанням статистичних методів, що включали параметричні та непараметричні тести, регресійний аналіз. Статистично достовірними отримані результати вважалися при $\mathrm{p}<0,05$.

Результати та обговорення. Процедура відновлення кровотоку в КА, які мали хронічну оклюзію, складалася з етапу механічної реканалізації з подальшою балонною ангіопластикою та стентуванням.

Оклюзії локалізувалися в проксимальному $(45,8 \%$ випадків, 167 пацієнтів) і середньому сегментах $(54,2 \%$ випадків, 198 пацієнтів) КА.

У 93 осіб $(25,5 \%)$ відзначалася хронічна оклюзія однієї КА. У 127 випадках $(34,79 \%)$ мала місце тривала оклюзія двох КА. У 56 (15,3\%) обстежених зазначалося хронічне ураження трьох КА. У 89 пацієнтів $(24,38 \%)$ було множинне атеросклеротичне ураження коронарного русла. Середня кількість уражених КА в досліджу-

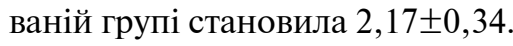

У пацієнтів і терміном оклюзії до 1 року (235 осіб) в 87,2\% випадків (205 пацієнтів) вдалося досягти хорошого ангіографічного результату. У $12,8 \%$ випадків (30 пацієнтів) відновлення кровотоку при ХКО виявилося безуспішним.

У пацієнтів із терміном ХКО від 1 року до 3 років (130 осіб) не вдалося реканалізувати ХКО в 27,7\% випадках (36 пацієнтів). Ангіографічний успіх склав 72,3\% випадків (94 пацієнти).

Середня кількість імплантованих стентів становила $2,12 \pm 0,3$ на одного пацієнта.

Процедурні ускладнення були розділені на великі і малі. До великих ускладнень були віднесені: смерть, клінічний інфаркт міокарда (який визначався як ішемічні симптоми з типовим підвищенням серцевих біомаркерів), тампонада серця, перфорація КА, кровотеча, що вимагала гемотрансфузії, гострий тромбоз стента, інсульт, екстрене шунтування коронарних артерій.

Малі ускладнення визначалися як ускладнення 3 боку судинного доступу, що не вимагали хірургічної корекції, нефропатії (спричинені впливом контрасту), кровотеча, що не відповідала критеріям серйозного ускладнення і не потребувала гемотрансфузії, тимчасова гемодинамічна нестабільність.

Загалом у 51 з 365 обстежених пацієнтів із ХКО $(13,97 \%)$ були перипроцедуральні ускладнення (табл. 1).

Більшість цих ускладнень були незначними (37 подій $-10,1 \%$ випадків) (табл. 1). Однак у 14 пацієнтів (3,8\% випадків) були зареєстровані «великі» перипроцедуральні ускладнення: летальний випадок $(0,27 \%)$, екстрене коронарне шунтування $(0,55 \%)$, інсульт/ транзиторна ішемічна атака $(0,27 \%)$, інфаркт міокарда, підтверджений клінічною картиною та динамікою кардіоспецифічних ферментів $(1,1 \%)$, тампонада $(0,27 \%$ - відбулося у пацієнта з дистальною перфорацією ар- 


\section{Таблиця 1}

Частота перипроцедуральних ускладнень, зареєстрованих у пацієнтів із хронічною коронарною оклюзією, при проведенні черезшкірних коронарних втручань

\begin{tabular}{lc} 
Ускладнення & $\begin{array}{c}\text { Кількість } \\
\text { ускладнень }\end{array}$ \\
\hline «Великі» ускладнення - $14(3,8 \%)^{*}$ & \\
\hline Летальний випадок & $1(0,27 \%)$ \\
\hline Екстрене АКШ & $2(0,55 \%)$ \\
\hline Інсульт / транзиторна ішемічна атака & $1(0,27 \%)$ \\
\hline Інфаркт міокарда & $4(1,1 \%)$ \\
\hline Тампонада & $1(0,27 \%)$ \\
\hline Перфорація КА & $2(0,55 \%)$ \\
\hline «Великі» кровотечі & $2(0,55 \%)$ \\
\hline Гострий тромбоз стента & $1(0,27 \%)$ \\
\hline
\end{tabular}

«Малі» ускладнення - $37(10,1 \%)^{*}$

Ускладнення з боку судинного доступу, 4 (1,1\%)

які не вимагали хірургічної корекції

\begin{tabular}{lc}
\hline Контраст-індукована нефропатія & $18(4,9 \%)$ \\
\hline «Малі» кровотечі & $12(3,28 \%)$ \\
\hline Транзиторна гіпотензія & $2(0,55 \%)$ \\
\hline Вазо-вагальна реакція & $1(0,27 \%)$
\end{tabular}

Примітка: АКШ - аортокоронарне шунтування; IM - інфаркт міокарда; КА - коронарна артерія; *- $=0,00124$

терії, яка розвинулася через 1 годину після закінчення успішної процедури), перфорація КА $(0,55 \%)$, кровотечі, що потребували проведення гемотрансфузії при зниженні рівня гемоглобіну до 70 г/л $(0,55 \%)$, гострий тромбоз стента $(0,27 \%)$ (табл. 1$)$.

Один летальний випадок у даній групі пацієнтів стався після безуспішних спроб реканалізації правої коронарної артерії, ускладненої тотальною оклюзією. Незважаючи на стабільність під час процедури, зупинка серцевої діяльності сталася через годину після закінчення процедури.

Екстрене аортокоронарне шунтування (АКШ) було виконано у 2 пацієнтів досліджуваної групи (табл. 1). В обох пацієнтів із вчасною реканалізацією лівої передньої низхідної КА і правої КА з використанням ретроградного підходу було зафіксовано ушкодження вінцевої судини. Хоча пацієнти залишалися гемодинамічно стабільними, КА не могли бути ре каналізовані, і хворим було виконано екстрене АКШ.

Перфорація КА реєструвалася в $0,55 \%$ випадках і була зумовлена використанням жорстких провідників, кальцифікацією та звивистими КА. В одному випадку дане ускладнення призвело до тампонади (табл. 1).

Такий же відсоток ускладнень був зареєстрований i при гострому тромбозі встановленого стента (табл. 1).
Найбільший відсоток ускладнень у цій групі припадав на IM (4 пацієнта - 1,1\% випадків) (табл. 1). В основі розвитку даного ускладнення лежала неможливість ефективно реканалізувати оклюзовану КА і тривалість ангіографічної процедури.

При цьому частота розвитку IM була порівнянна між процедурами, які мали $100 \%$ ангіографічний успіх, і процедурами, які не дозволили провести ефективну реканалізацію (2 пацієнти з ефективною реканалізацією $(0,55 \%)$ і 2 пацієнти при невдалій реканалізації $(0,55 \%))$.

Порівняно з успішними процедурами невдалі процедури мали значно вищі показники «великих» перипроцедуральних ускладнень: $11(3,01 \%)$ проти $3(0,8 \%)$, інсульт $-1(0,27 \%)$ проти $0 \%, \mathrm{IM}-3(0,8 \%)$ проти 1 $(0,27 \%)$, тампонада - $1(0,27 \%)$ проти $0 \%$ (рис. 1$)$. «Малі» ускладнення при виконанні рентген-ендоваскулярних процедур у пацієнтів з ХКО були зафіксовані в $10,1 \%$ випадків (табл. 1).

Найбільш частими незагрозливими ускладненнями були контраст-індукована нефропатія (4,9\%), незначні кровотечі $(3,28 \%)$ і ускладнення з боку судинного доступу, що не потребували хірургічної корекції $(1,1 \%)$. Решта ускладнень були рідкісними $(<0,6 \%$ випадків) (табл. 1).

Контрастна нефропатія була пов'язана з несприятливими клінічними результатами і включала в себе тривале перебування в лікарні і прогресування хронічної ниркової патології. В одному випадку через тиждень після виконання ангіографічної операції хворому знадобилося проведення декількох процедур гемодіалізу.

Зареєстровані нами незначні кровотечі були спричинені використанням інтродьюсерів великого калібру і неодноразових невдалих спроб пункції стегнової артерії. При цьому дане ускладнення фіксувалося

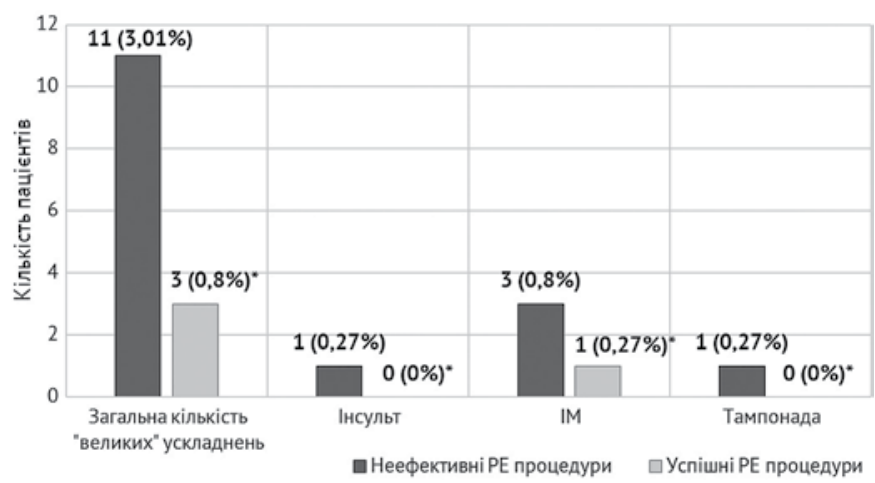

Рис. 1. Кількість ускладнень при ефективних і неефективних рентген-ендоваскулярних процедурах у пацієнтів із хронічною оклюзією коронарних артерій (Примітка: * - p<0,05; IM - інфаркт міокарда; PE-процедури - рентген-ендоваскулярні процедури). 


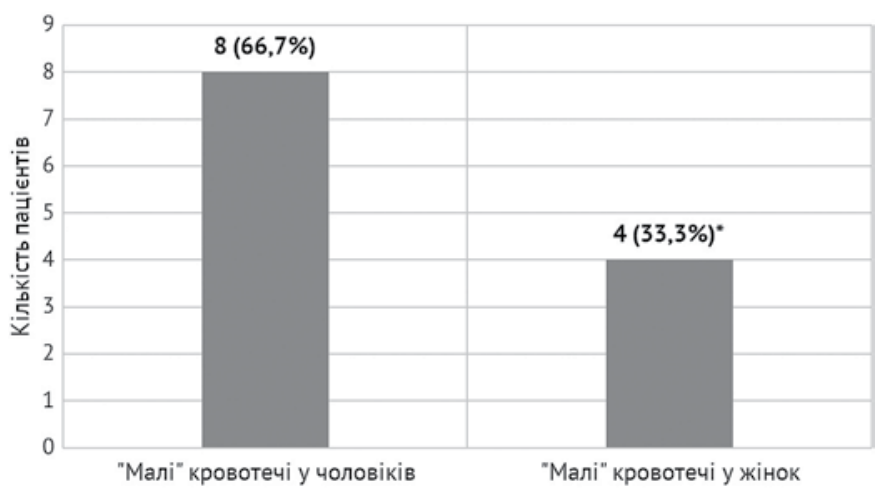

Рис. 2. Розподіл «малих» кровотеч серед чоловіків і жінок із ХКО після ангіографічних прочедур

(Примітка: * $-p=0,00136)$

на $33,3 \%$ частіше у жінок, ніж у чоловіків $(\mathrm{p}=0,00136)$ (рис. 2).

\section{Висновки}

1. Найбільший відсоток ускладнень у досліджуваній групі припадав на IM (1,1\% випадків). В основі розвитку даного ускладнення лежала неможливість ефективно реканалізувати оклюзовану КА і тривалість ангіографічної процедури. При цьому частота розвитку ІМ була порівнянна між процедурами, які мали $100 \%$ ангіографічний успіх, і процедурами, які не дозволили провести ефективну реканалізацію.

2. Порівняно з успішними процедурами невдалі процедури мали значно вищі показники «великих» перипроцедуральних ускладнень.

3. Найбільший відсоток «малих» ускладнень припадав на контраст-індуковану нефропатію $(4,9 \%)$, незначні кровотечі $(3,28 \%)$ і ускладнення з боку судинного доступу, що не потребували хірургічної корекції $(1,1 \%)$.

\section{Література}

1. Current perspectives on coronary chronic total occlusions: the Canadian Multicenter Chronic Total Occlusions Registry / P. Fefer, M. L. Knudtson, A. N. Cheema [et al.] // J. Am. Coll. Cardiol. - 2012. - Vol. 59, № 11. P. 991-997.
2. Brott B. C. The safety and outcomes of chronic total occlusion interventions / B. C. Brott // JACC Cardiovasc. Interv. - 2013. - Vol. 6, № 2. - P. 137-138.

3. Angiographic success and procedural complications in patients undergoing retrograde percutaneous coronary chronic total occlusion interventions: a weighted metaanalysis of 3,482 patients from 26 studies / A. El Sabbagh, V. G. Patel, O. M. Jeroudi [et al.] // Int. J. Cardiol. 2014. - Vol. 174, № 2. - P. 243-248.

4. Angiographic success and procedural complications in patients undergoing percutaneous coronary chronic total occlusion interventions: a weighted meta-analysis of 18,061 patients from 65 studies / V. G. Patel, K. M. Brayton, A. Tamayo [et al.] // JACC Cardiovasc. Interv. - 2013. Vol. 6, № 2. - P. 128-136.

5. Clinical, angiographic, and procedural predictors of periprocedural complications during chronic total occlusion percutaneous coronary intervention / V. G. Patel, T. T. Michael, O. Mogabgab [et al.] // J. Invasive Cardiol. 2014. - Vol. 26, № 3. - P. 100-105.

6. Procedural and in-hospital outcomes after percutaneous coronary intervention for chronic total occlusions of coronary arteries 2002 to 2008: impact of novel guidewire techniques / S. Rathore, H. Matsuo, M. Terashima [et al.] // JACC Cardiovasc. Interv. - 2009. - Vol. 2, № 6. -P. 489-497.

7. Frequency and outcomes of aortocoronary dissection during percutaneous coronary intervention of chronic total occlusions: a case series and systematic review of the literature / D. Shorrock, T. T. Michael, V. Patel [et al.] // Catheter Cardiovasc. Interv. - 2014. - Vol. 84, № 4. P. 670-675.

8. Frequency, treatment, and consequences of device loss and entrapment in contemporary percutaneous coronary interventions / J. M. Iturbe, A. R. Abdel-Karim, A. Papayannis [et al.] // J. Invasive Cardiol. - 2012. Vol. 24, № 5. - P. 215-221.

9. Long-term outcome of percutaneous coronary intervention for chronic total occlusions / R. Mehran, B. E. Claessen, C Godino [et al.] // JACC Cardiovasc. Interv. - 2011. Vol. 4, № 9. - P. 952-961.

10. A percutaneous treatment algorithm for crossing coronary chronic total occlusions / E. S. Brilakis, J. A. Grantham, S. Rinfret [et al.] // JACC Cardiovasc. Interv. - 2012. Vol. 5, № 4. - P. 367-379.

\title{
Analysis of complications of endovascular recanalization in patients with chronic coronary occlusion
}

\author{
Aksenov E. V., Golovenko V. B. \\ National M. M. Amosov Institute of Cardiovascular Surgery National Academy of Medical Sciences of Ukraine (Kyiv)
}

The work is devoted to the study and analysis of complications during endovascular recanalization of chronic coronary occlusion (CCO) in patients with with ischemic heart disease.

The survey included 365 patients with $\mathrm{CCO}$, which are conducted diagnostic and treatment interventions for this pathology on the basis of the angiographic department National Institute of N. Amosov Cardiovascular Surgery.

The average age of patients was $66,96 \pm 1,81$ years, average weight $-86,5 \pm 1,44 \mathrm{~kg}$. 
Duration of occlusion was determined from the moment of myocardial infarction in the basin of the infarct-linked coronary artery (CA).

The duration of occlusion from 3 to 6 months was observed in $26.8 \%$ of patients (98 patients). The period of occlusion from 6 to 12 months was registered in $37.5 \%$ of patients ( 137 people). The total duration of occlusion from 1 year to 3 years was $35.6 \%$ of patients (130 patients).

As a result of the performed research, it was determined that the highest percentage of complications in the study group was in the MI (1.1\% of cases). At the heart of the development of this complication was the impossibility of effectively recanalizing the occluded CA and the duration of the angiographic procedure. In this case, the incidence of MI was comparable between procedures that had $100 \%$ angiographic success and in procedures that prevented an effective recanalization.

In comparison with successful procedures, unsuccessful procedures had significantly higher rates of «large» periprocedural complications.

The highest percentage of «small» complications included contrast-induced nephropathy (4.9\%), minor bleeding $(3.28 \%)$, and complications from vascular access that did not require surgical correction (1.1\%).

Key words: recanalization, chronic occlusion, coronary artery. 